\title{
DESIGN AND OPTIMIZATION OF PCM-AIR COLD ENERGY STORAGE DEVICE TO BE USED FOR PEAK ELECTRICITY SHAVING
}

\author{
Göker TÜRKAKAR \\ Zonguldak Bülent Ecevit University, Mechanical Engineering Department Zonguldak, Turkey \\ turkakar@beun.edu.tr, ORCID: 0000-0002-5468-604X
}

(Geliş Tarihi: 24.03.2020, Kabul Tarihi: 25.11.2020)

\begin{abstract}
Parametric analysis and dimensional optimization study for the melting process of the phase changing material placed in cold energy storage devices have been conducted. Phase changing material, PCM, is used to store the cold energy. A cross-flow tubular PCM-air heat exchanger is used. An electricity peak shaving for a summer day in Antalya for 5 hours (10:00-15:00) is aimed. The cooling load of a room (33 $\left.\mathrm{m}^{2}\right)$ in Antalya is taken as a reference value. A minimum cooling load of $2850 \mathrm{~W}$ is supplied throughout 5 hours to maintain the building's comfort temperature. Contrary to the studies handling air velocity constant, it is varied during melting in the present study to satisfy the minimum cooling load. The melting process is analyzed using a numerical model. A computational algorithm is implemented in MATLAB environment. The numerical model is validated for the same conditions and the dimensions with an analytical model presented in the literature. A transient analysis has been employed, and the problem is discretized for the time and space domain. A dimensional optimization algorithm is employed. A parameter "performance ratio/ cooling index", the ratio of total cooling to fan energy consumption, is defined. Spacing between the tubes giving the maximum performance ratio is sought for aligned and staggered tube bank arrangements using this algorithm. The best performance ratio is obtained at $0.2 \mathrm{~m} / \mathrm{s}$ initial velocities for both arrangements. In addition, the effect of sizing/arrangement of the tubes, PCM mass, and thermal conductivity of the PCM on the melting characteristics is investigated. As a result of increasing the thermal conductivity from $0.2 \mathrm{~W} /(\mathrm{m} \cdot \mathrm{K})$ to $0.6 \mathrm{~W} /(\mathrm{m} \cdot \mathrm{K})$, the performance ratios are raised 4.58 and 3.52 times for aligned and staggered orders, respectively. It is calculated that $10 \mathrm{~kg}$ PCM can be saved thanks to enhancing the thermal conductivity of the PCM.
\end{abstract}

Keywords: Cold energy storage, Phase change materials, PCM-air heat exchanger.

\section{ELEKTRİKTE PİK TALEBİ TÖRPÜLEME İÇIN KULLANILACAK FDM-HAVA SOĞUK ENERJI DEPOLAMA CIHAZI TASARIMI VE OPTIMIZASYONU}

Özet: Soğuk enerji depolama cihazındaki faz değişim malzemesinin ergime sürecinin parametrik analiz ve boyutsal optimizasyon çalışması yürütülmüştür. Faz değişim malzemesi FDM, soğuk enerjiyi depolamak için kullanılır. Çapraz akışılı borulu FDM-hava 1sı değiştiricisi kullanılmıştır. Antalya'da bir yaz günü için 5 saat boyunca elektrikte pik talebi törpüleme amaçlanmıştır. Antalya'da $33 \mathrm{~m}^{2}$ 'lik bir odanın soğutma yükü referans değer olarak alınmıştır. Binanın 5 saat boyunca sıcaklığını sabit tutmak için gerekli soğutma yükü olan minimum 2850 W'lık soğutma sağlanmıştır Hava hızını sabit olarak ele alan çalışmaların aksine; bu çalışmada minimum soğutma yükünü karşılayabilmek amacıyla ergime süreci boyunca hava hızı değiştirilmiştir. Ergime süreci sayısal bir model ile analiz edilmiştir. Hesaplama algoritması MATLAB ortamında uygulanmıştır. Sayısal model aynı boyutlar ve koşullar için literatürdeki bir çalışma ile kıyaslanarak doğrulanmıştır. Zamana bağlı analiz yürütülmüş olup, problem zaman ve konum için ayrıklaştırılmıştır. Boyutsal optimizasyon algoritması ele alınmıştır. Toplam ısı geçişinin toplam fan enerji tüketimine oranı olarak bilinen "performans oranı/ soğutma indeksi” parametresi tanımlanmıştır. Bu algoritma ile sıralı ve kademeli demeti dizilimleri için performans oranını maksimize eden borular arası optimum mesafeler araştırılmıştır. En iyi performans oranı her iki düzen için de $0.2 \mathrm{~m} / \mathrm{s}$ başlangıç hızı için elde edilmiştir. Ayrıca boruların boyut/dizilim, FDM kütlesi ve 1Sı iletim katsayısının FDM ergime karakteristiğine etkisi incelenmiştir. FDM 1sı iletim katsayısının $0.2 \mathrm{~W} /(\mathrm{m} \cdot \mathrm{K})$ 'den 0.6 $\mathrm{W} /(\mathrm{m} \cdot \mathrm{K})$ 'ye çıkarılması sonucu performans katsayısının sıralı ve kademeli dizilim için sırasıyla 4.58 ve $3.52 \mathrm{~kat}$ arttığı bulundu. Isı iletim katsayısının iyileştirilmesi sonucu FDM'den $10 \mathrm{~kg}$ tasarruf edilebileceği hesaplandı. Anahtar kelimeler: Soğuk enerji depolama, Faz değişim malzemeleri, FDM-hava 1sı değiştiricileri

$\begin{array}{llll}\text { NOMENCLATURE } & f^{\prime} & \text { friction factor } \\ & f_{m} & \text { melt fraction } \\ A_{o} & \text { heat tr. area based on outer surface }\left[\mathrm{m}^{2}\right] & h & \text { heat transfer coefficient }\left[\mathrm{W} /\left(\mathrm{m}^{2} \mathrm{~K}\right)\right] \\ C_{\text {air }} & \text { heat capacity of the air }[\mathrm{W} / \mathrm{K}] & h_{s l} & \text { latent heat of fusion }[\mathrm{J} / \mathrm{kg}] \\ D & \text { diameter } & H & \text { HEX height }[\mathrm{m}]\end{array}$




$\begin{array}{ll}k & \text { thermal conductivity }[\mathrm{W} /(\mathrm{mK})] \\ L & \text { total HEX length }[\mathrm{m}] \\ \mathrm{m}_{\mathrm{pcm}} & \text { total mass of the PCM } \\ \dot{m} & \text { mass flow rate }[\mathrm{kg} / \mathrm{s}] \\ \mathrm{N}_{\mathrm{T}} & \text { number of tubes per row } \\ \mathrm{N}_{\mathrm{L}} & \text { number of tube row } \\ \mathrm{q} & \text { heat transfer }[\mathrm{J}] \\ \dot{q} & \text { heat transfer }[\mathrm{W}] \\ P & \text { pressure }[\mathrm{Pa}] \\ \mathrm{Re} & \text { Reynolds number } \\ S_{L} & \text { Tube spacing in the flow direction }[\mathrm{m}] \\ S_{T} & \text { Tube spacing in the transverse flow dr. }[\mathrm{m}] \\ t & \text { time, thickness } \\ T_{R} & \text { room comfort temperature }[\mathrm{K}] \\ U & \text { Overall heat tr. coef. }\left[\mathrm{W} /\left(\mathrm{m}^{2} \mathrm{~K}\right)\right] \\ u_{\infty} & \text { mean air velocity }[\mathrm{m} / \mathrm{s}] \\ \mathrm{V} & \text { volume }\left[\mathrm{m}^{3}\right] \\ v & \text { specific volume }\left[\mathrm{m}^{3} / \mathrm{kg}\right] \\ W & \text { total HEX width }[\mathrm{m}] \\ \mathbf{G r e e k} & \text { Letters } \\ \eta & \text { fan efficiency } \\ \dot{\forall} & \text { volumetric flow rate }\left[\mathrm{m}^{3} / \mathrm{s}\right] \\ \rho & \text { density }\left[\mathrm{kg} / \mathrm{m}^{3}\right] \\ \mu_{b} & \text { average free stream viscosity, }\left[(\mathrm{N} \cdot \mathrm{s}) / \mathrm{m}^{2}\right] \\ \mathrm{Subsc}\end{array}$

\section{Subscripts}

air air

i inner

in inlet

init initial

1 liquid

Im logarithmic mean

m melting

out outer

pcm phase change material

s surface, solid

t total, tube

\section{Superscripts}

$\mathrm{p}$ time interval

\section{INTRODUCTION}

Phase change materials, PCM, are widely used in energy storage and thermal management applications thanks to their high latent heat of fusion values. In addition to sensible heat storage capacity, PCMs can store high amounts of energy while maintaining its temperature stable around the melting temperature. They are mainly used in the area of electronics cooling, solar energy storage systems, building heating/cooling energy storage applications, battery thermal management systems, cold chain logistics, and photovoltaic panel's cooling applications. There are many studies related to heating/cooling applications of the buildings with PCM in the literature (Chaiyat et al., 2014). In cold energy storage systems for building applications, PCM's are generally located in the ceiling of the building. PCM is solidified with nighttime cool air with the help of a fan. Stored cold energy is released during the daytime by a fan or natural convection effect (Souayfane et al., 2016). Therefore, PCM use for building cooling applications is reasonable for the regions where the temperature difference of night and the daytime is high. Some studies stored the cold energy using vapor compression refrigeration systems. Taking advantage of cold air and low electricity cost in the nighttime, PCM use in building cooling applications has become feasible. PCM placed in the specifically designed evaporator section of the refrigeration cycle should effectively store and supply the thermal energy. A similar case is valid for PCM-air heat exchangers, which are used in building cooling applications. PCM-air heat exchangers are used to storing cold energy supplied by nighttime outdoor cold air or by refrigerated cold air. The melting period of fully solidified PCM by the refrigerated air flow in the nighttime is analyzed in the current work. Stored cold energy is provided by forced airflow in the daytime, so the building's temperature is kept at comfort temperature. In the present study, the melting characteristics of the tubular cross flow PCM-air cold energy storage HEX unit is examined. Parameters affecting this type of HEX's performance are the air mean velocity, the diameter of the tubes, tube arrangement, the distance between the tubes, thermal conductivity of the PCM, and mass of the PCM. Considering these parameters, PCM-air heat exchangers should be designed to require minimum electricity caused by the fan while satisfying the necessary cold energy requirement. Besides, the use of PCM mass should be kept minimum because of their high cost. The design should comply with the other components of the system and reduce the energy cost. Hence, it is essential to conduct a parametric analysis and optimize the dimension of the heat exchanger. For such a system, PCM mass and the fan power should be minimized. Detailed information about the present study's scope is provided in the last paragraph of the Introduction section.

Due to the melting process's natural characteristics, total heat transfer absorbed by the PCM reduces with time for the constant airflow velocity. Therefore, mean air velocity should be increased as the melt fraction increases so that the constant heat transfer is provided. Studies in the literature related to PCM-Fluid HEX have examined the HEX melting performance for the constant fluid velocity (Koz and Khalifa, 2018; Dubovsky et al., 2011; Asker and Günerhan, 2016). In this case, HEX performance gets poorer as the melt fraction rises, and it is not possible to keep the room at comfort temperature. It is more reasonable to use an adjustable speed fan and dynamically modify the fan speed according to the cooling demand that changes with time.

Thermal energy storage with PCMs has attracted the attention of researchers in recent years. Researchers have designed, simulated, and tested various types of PCM-air 
heat exchangers. Some researchers have focused on packed bed systems (Chaiyat et al., 2014; Fang et al., 2010). In these studies, PCM is filled in capsuled, and air/water is used for the charge or discharge process. Packed bed energy storage systems are used for building cooling or heating processes. Besides, PCM encased parallel slabs are used in several studies (Koz and Khalifa, 2018; Hed and Bellander, 2006, Kuznik et al., 2015). Air is flowing through the parallel slabs and melt/freeze the PCM. They both theoretically and experimentally analyzed the system. Koz and Khalifa (2018) have explored the effects of the slab thickness, distance between the slabs, and PCM thermal conductivity on the cold energy storage device's melting performance. They aimed to create a microenvironmental control system (local cooling for a person) and provide more than $50 \mathrm{~W}$ cooling at the end of the $8.5 \mathrm{~h}$ cooling period under a constant air flow rate. Hed and Bellander (2006) developed an algorithm of PCM-air heat exchanger to be used in the building. A numerical model is developed using the finite-difference model, and results are compared with the prototype heat exchanger. Air is flowing (air gap is $8 \mathrm{~mm}$ ) through $8 \mathrm{~mm}$ thick PCM slabs. The heat transfer coefficient is calculated using the Reynolds Colburn analogy using the rough surface. Simulations and tests have been performed for constant airflow and inlet temperature. The results of the simulations and the experiments have matched well. Kuznik et al. (2015) have designed a PCM to air rectangular heat exchanger using dimensionless parameters. The air was flowing through PCM slabs. The aim was electricity peak shaving (for 2 hours) for a winter day in France. They have developed a methodology for a specific geometry of the storage unit. This methodology determines the suitable PCM and the PCM's thermal conductivity satisfying the required specifications of the application. Erdemir and Altuntop (2018) have performed experimental work to reduce a hypermarket's cooling cost using encapsulated ice thermal storage system. The storage system is integrated with the air conditioning system of the hypermarket. They noted that the stored energy needs to be used in electricity peak hour as much as possible. The shortest payback period is 1.5 years in both load leveling and $10 \%$ partial storage strategies.

There are some studies using shell and tube heat exchangers as TES units. Zhao and Tan (2015) used shell and tube type HEX unit with fins to increase the coefficient of performance, COP, of the air-conditioning system. They have developed a numerical model for the analyses. While the PCM in the HEX serves as a heat sink for the air conditioner (condenser heat rejection) in the daytime, PCM freezes thanks to the cold nighttime air. Air is used to freeze the PCM, and water melts the PCM in the daytime. They reported that COP is increased by about $25.6 \%$ with the help of PCM-air-water shell and tube HEX. Dhumane et al. (2019) used PCM to store condenser heat to improve the vapor compression cycle performance's performance. Dhumane et al. (2019) have designed and tested shell and tube type PCM-HEX with helical coils. They employed a dynamic model to analyze the system using Modelica software. They have investigated the melting temperature of the PCM, maximizing the COP of the system. As a result of the experiments, an increase of $11 \%$ in the COP is observed.

Dubovsky et al. (2011) have analyzed the melting of a PCM-air heat exchanger storage unit both analytically and numerically. Crossflow tubular HEX is investigated. Tubes are filled with the PCM. Air is a fan-driven across aligned order tube banks. They have investigated timedependent parameters like PCM melt fraction, heat transfer rate, air temperature analytically. The numerical solution has supported the prediction ability of the developed analytical model. Asker and Günerhan (2016) have conducted a parametric study for similar geometry with Dubovsky et al. (2011). They numerically investigated the effects of the tube interval, fan speed, PCM material on total melting time.

Generally, studies related to the PCM-air storage units have conducted their simulations at a constant airspeed. Due to the melting process's natural characteristics, total heat transfer absorbed by the PCM reduces with time at the constant airflow velocity. This situation makes it difficult to maintain the building's temperature at the comfort level for a certain period. The use of a variable speed fan during the melting process tolerates the drawback of the low heat transfer performance towards the end of melting. However, fan speed increase brings about the increase in the pressure drop and the pumping power. That is why a new parameter, which is the ratio of total heat transfer to the fan's energy requirement, is defined. The heat exchanger is designed and analyzed such that it would provide minimum cooling of $2850 \mathrm{~W}$ cooling for 5 hours. An electricity peak shaving is aimed, using a cold energy storage unit at this period. A time-dependent melting analysis is conducted numerically for a cross-flow tubular PCM-air heat exchanger. Distinctive to the studies in the literature, airspeed is adjusted without exceeding a critical pumping power value so that the constant heat transfer can be provided for a certain period. Contrary to most of the studies focusing on parametric analysis in the literature, a dimensional optimization study for a PCM-air cold energy storage HEX has been conducted for variable air velocity. Both aligned and staggered tube bank order is analyzed, dimensionally optimized, and their performance is compared. The study aims to find an optimum configuration and dimensions of the cross-flow tubular PCM-air heat exchanger for the specified conditions and constrictions while minimizing the fan energy consumption and PCM mass.

\section{PROBLEM DEFINITION}

In this section, the geometry and the dimensions of the cross-flow tubular PCM-air heat exchanger are given. Besides, governing equations of the melting process are provided.

\section{Geometry and Assumptions}

PCM-air HEX is intended to provide comfort temperature $\left(25^{\circ} \mathrm{C}\right)$ of a room $\left(33 \mathrm{~m}^{2}\right)$ of a building 
located in Antalya/TURKEY on the date of $21^{\text {th }}$ of July (10:00-15:00) during which electricity demand peaks. The cooling load of the mentioned room is provided in Table 1.

Table 1. Cooling Load of the room (Erkmen and Gedik, 2007)

\begin{tabular}{|c|c|}
\hline Time Interval & Cooling Load, W \\
\hline 10:00-11:00 & 2870 \\
\hline $11: 00-12: 00$ & 2768 \\
\hline $12: 00-13: 00$ & 2803 \\
\hline $13: 00-14: 00$ & 2887 \\
\hline $14: 00-15: 00$ & 2927 \\
\hline
\end{tabular}

If $2850 \mathrm{~W}$ (mean value) of cooling power is handled, the room comfort temperature can be kept at around comfort temperature with slight changes. The minimum cooling load of $2850 \mathrm{~W}$ during the $5 \mathrm{hr}$ period is considered a reference value in the present study. The air inlet temperature to the HEX is fixed at the room comfort temperature, $25^{\circ} \mathrm{C}$. Fully solidified PCM by the refrigerated air in the nighttime is discharged during the daytime. The schematic of the system is depicted in Fig. 1 .

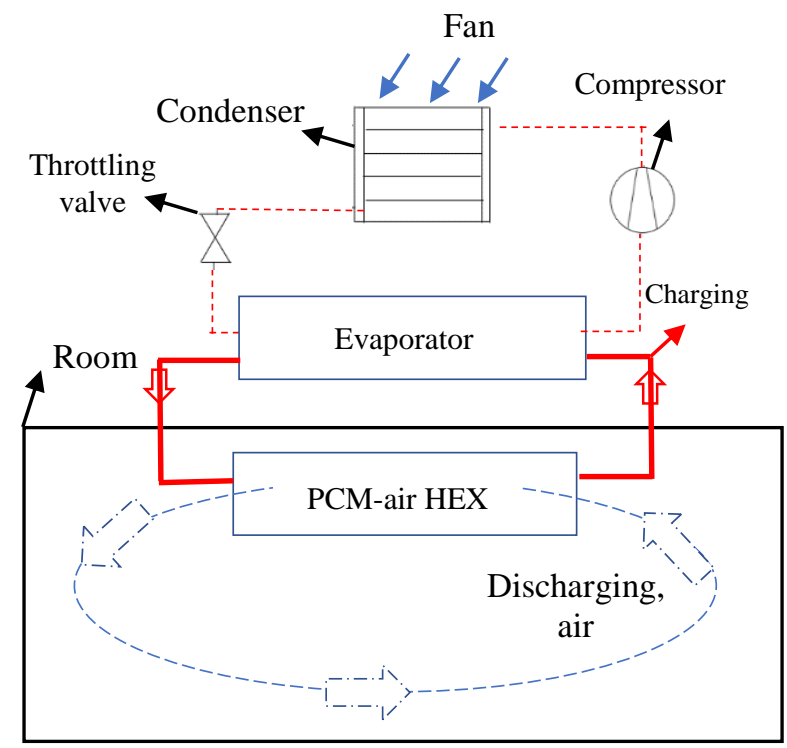

Figure 1. Schematic of the system

Heat exchangers are generally evaluated for steady-state conditions. As the hot/cold energy is stored in PCM-air HEX, a transient solution is necessary. HEX consists of a tube bundle, and the PCM is placed inside the tubes. Aligned and staggered tube arrangements in the HEX are examined separately. The thermal and hydrodynamic behavior of these arrangements is distinctive as the velocity profile inside the HEX differs. Therefore, the best performing configuration is sought. The air temperature varies by time and by location as well. The melt ratio is different for all tube rows at a specific instant. Thus, for a specific period, the geometries shown in Fig 2 and Fig 3 are divided into segments in the streamwise direction for the aligned and staggered arrangements, separately. Thermal and hydrodynamic calculations are evaluated for each tube row. After completing the calculations for a specific time period, calculations are performed for the following time step using the current time step results. General geometries and the computational domains for aligned and staggered geometry are provided in Fig. 2 and Fig. 3, respectively.

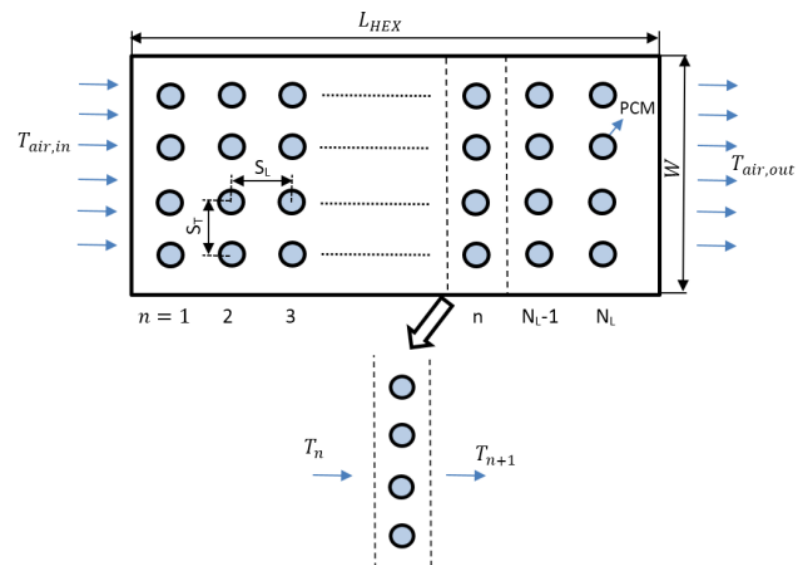

Figure 2. General view of the PCM-air heat exchanger (Aligned order) and computational domain

The general geometry of staggered order tube bank PCMair HEX is given in Fig 3.

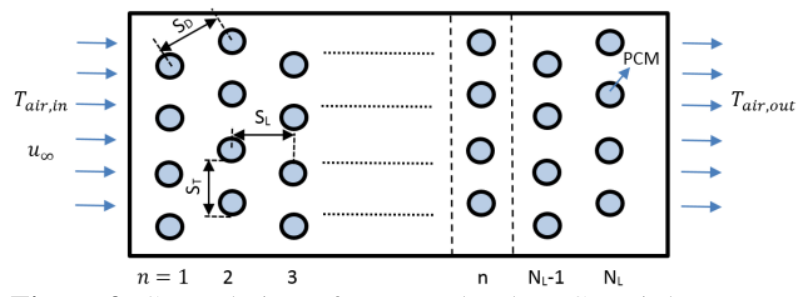

Figure 3. General view of staggered order PCM-air heat exchanger

As many cases are evaluated to find the optimum dimensions and operating conditions, it is necessary to simplify the complexity of the problem and reduce the computational effort. The problem is discretized in the time domain. In each time step, the First Law of Thermodynamics is handled by neglecting kinetic and potential energy changes in the air. Axial conduction (flow direction) in the air is also neglected. Heat transfer between the PCM and the air is found using the overall heat transfer coefficient. The air-side heat transfer coefficient is obtained using experimental tube bank correlations. It is assumed that the PCM is in the melting temperature (completely solid at the beginning of the melting process), so the sensible heat transfer effect is neglected. For the temperature range $\left(18-25^{\circ} \mathrm{C}\right)$ at which the problem is handled, the PCM's sensible heat capacity is less than $6 \%$ of the latent heat of fusion of it. The sensible heat effect of the tube material is also negligible because its mass is less than the PCM material. Mass of the tube material changes case by case, but its sensible heat effect corresponds to approximately $4 \%$ of the PCM's latent heat of fusion capacity. The convection effect in the liquid layer formed during PCM melting is neglected, so only the heat conduction effect in the liquid layer is put into account as it is done in many studies in 
the literature (Dubovsky et al., 2011; Asker and Günerhan, 2016).

\section{Governing Equations}

Thermal and hydrodynamic calculations are provided as two subsections in this part.

\section{Thermal calculations}

The energy balance for the control volume shown in Fig 2 (or Fig. 3) is given in Eq. (1). It is essential to remind that the PCM's heat is discharged only through latent heat of fusion. The PCM is at the melting temperature initially. Kinetic and potential energy changes are neglected in Eq. (1),

$$
\begin{aligned}
q_{n}^{p}=\dot{m}_{\text {air }} C_{p, a i r} & \left(T_{a i r, n}^{p}-T_{a i r, n+1}^{p}\right)=U_{n}^{p} A \Delta T_{l m, n}^{p} \\
& =U_{i, n}^{p} A_{i} \Delta T_{l m, n}^{p}
\end{aligned}
$$

As the time and space domain is discretized, it is necessary to represent them in the formulas. Superscript, p, represents the time step of the analysis. Similarly, subscript $\mathrm{n}$ refers to the control volume (tube row) number. If the parameters are to be explained in Eq. (1); the air mass flow rate can be expressed as $\dot{m}_{\text {air }}=u_{\infty} \rho_{\text {air }}(W \cdot H), A_{i}$ is the total heat transfer surface area of a tube row (depicted in Fig. 2) and given as $A_{i}=\pi D_{i} H N_{T}$. Logarithmic mean temperature difference (LMTD) is defined as

$$
\Delta T_{l m}=\frac{\left(T_{\text {air }, n}^{p}-T_{\text {melt }}\right)-\left(T_{\text {air }, n+1}^{p}-T_{\text {melt }}\right)}{\ln \left(\frac{T_{\text {air }, n}^{p}-T_{\text {melt }}}{T_{\text {air }, n+1}^{p}-T_{\text {melt }}}\right)}
$$

To find the air outlet temperature of a segment from the Eq. (1), the thermal resistances and the overall heat transfer coefficient needs to be calculated. Neglecting the convection effect of the PCM liquid layer, the overall heat transfer coefficient, U, is given in Eq. (3) as

$$
\begin{aligned}
\frac{1}{U A}=\frac{1}{U_{i, n}^{p} A_{i}}= & \frac{\ln \left(D_{i} / D_{s l, n}^{p}\right)}{2 \pi k_{p c m, l} H}+\frac{\ln \left(D_{o} / D_{i}\right)}{2 \pi k_{t u b e} H} \\
& +\frac{1}{h_{\text {air }}\left(\pi D_{o} H\right)}
\end{aligned}
$$

$D_{s l, n}^{p}$ is the diameter of the solid-liquid interface. The diameter of the solid-liquid interface varies for each tube row. The first term in Eq. (3) is the time and spacedependent liquid layer conduction thermal resistance. It depends on the thickness of the liquid layer formed during melting. Time and space-dependent overall heat transfer coefficient is given in Eq. (4),

$$
\frac{1}{U_{i, n}^{p}}=\frac{D_{i} \ln \left(D_{i} / D_{s l, n}^{p}\right)}{2 k_{p c m, l}}+\frac{D_{i} \ln \left(D_{o} /_{D_{i}}\right)}{2 k_{\text {tube }}}+\frac{D_{i}}{h_{\text {air }} D_{o}}
$$

Melt fraction, $f_{n}^{p}$ is the ratio of the liquid mass of the PCM to the total mass of the PCM for a computational domain. At the beginning of the analysis $(t=0 \mathrm{~s})$, the melt fraction is zero. It means that all PCM is in the solid phase initially. Melt fraction for the following time step can be calculated using the Eq. (5),

$f_{n}^{p+1}=f_{n}^{p}+\frac{q_{n}^{p} \Delta t}{m_{\text {pcm,row }} h_{s l}}$

$m_{p c m, \text { row }}$ is the total mass in the tubes per row (number of tubes in the transverse direction), and it can be calculated as $m_{p c m, \text { row }}=\rho_{P C M, l} V_{\text {tube }} N_{T}$. For the same density of the liquid and solid phases of the PCM, melt fraction can be expressed as

$f_{n}^{p}=1-\left(\frac{D_{s l, n}^{p}}{D_{i}}\right)^{2}$

If the time-dependent conduction thermal resistance of the liquid layer in Eq. (4) is expressed in terms of $f_{n}^{p}$,

$\frac{1}{U_{i, n}^{p}}=\frac{-D_{i} \ln \left(1-f_{n}^{p}\right)}{4 k_{p c m, l}}+\frac{D_{i} \ln \left(D_{o} / D_{i}\right)}{2 k_{\text {tube }}}+\frac{D_{i}}{h_{\text {air }} D_{o}}$

The average heat transfer coefficient for aligned/staggered order tube bank is calculated using a correlation proposed by Zukauskas (1972), Incropera and DeWitt (2002).

$\overline{N u}_{D}=C_{1} R e_{D, \max }^{m} \operatorname{Pr}^{0.36}\left(\frac{P r}{P r_{S}}\right)^{1 / 4}$

$\left\{\begin{array}{c}N_{L} \geq 20 \\ 0.7 \lesssim \operatorname{Pr} \lesssim 500 \\ 10 \lesssim R e_{D, \text { max }} \lesssim 2 \times 10^{6}\end{array}\right\}$

All properties except $\mathrm{Pr}_{s}$ are evaluated at an arithmetic average of HEX inlet and outlet temperatures. $\mathrm{C}_{1}$ is a constant, and its value depends on the $R e_{D, \max }$ (Incropera and DeWitt, 2002). Reynolds number is based on the maximum velocity occurring in the tube bank is defined as

$R e_{D, \max }=\frac{\rho u_{\max } D}{\mu}$

Maximum velocity occurring in the tube bank for the aligned order is given in Eq. (10) as

$u_{\max }=\frac{S_{T}}{S_{T}-D} u_{\infty}$

Maximum velocity occurring in the tube bank for the staggered order is derived using conservation of mass for the incompressible flow and given in Eq. (11), 
$u_{\max }=\frac{S_{T}}{2\left(S_{D}-D\right)} u_{\infty}$

A dimensionless time-dependent heat transfer is defined. It is a ratio of heat transfer in the HEX to the maximum possible heat transfer in the HEX.

$q_{0}^{p}=\frac{\sum_{n=1}^{N_{L}} q_{n}^{p}}{\dot{m}_{\text {air }} C_{p, \text { air }}\left(T_{\text {air }, \text { in }}-T_{\text {melt }}\right)}$

A criterion for the performance of the HEX is defined. It is named as performance ratio or cooling index (Yang et al., 2015). It is the ratio of the total energy absorbed by the HEX during melting to the fan's energy consumption. This ratio is expressed in Eq. (13).

$P R=\frac{\sum_{p=1}^{t_{\text {total }} / \Delta t} \sum_{n=1}^{N_{L}} q_{n}^{p} \Delta t}{\sum_{p=1}^{t_{\text {total }} / \Delta t} W_{\text {fan }}^{p} \Delta t}$

\section{Hydrodynamic calculations}

The pressure drop in the HEX can be calculated using Eq. (14). As a variable speed fan is used in the analysis, pressure drop and the fan power are time-dependent parameters.

$\Delta P^{P}=\frac{2 f^{\prime P}\left(G_{\max }^{p}\right)^{2} N_{L}}{\rho_{\text {air }}}\left(\frac{\mu_{w}}{\mu_{b}}\right)^{0.14}$

The density of air is evaluated for free stream conditions. $f^{\prime}$ is the friction factor that is given far aligned and staggered order tube banks in Eq. (15) and Eq. (16), respectively.

$f^{\prime P}=\left\{0.044+\frac{0.08\left(\frac{S_{L}}{D_{\text {out }}}\right)}{\left[\frac{S_{T}-D_{\text {out }}}{D_{\text {out }}}\right]^{0.43++1.13\left(\frac{D_{\text {out }}}{S_{L}}\right)}}\right\}\left(R e_{\text {max }}^{p}\right)^{-0.15}$

$f^{\prime P}=\left\{0.25+\frac{0.118}{\left[\frac{S_{T}-D_{\text {out }}}{D_{\text {out }}}\right]^{1.08}}\right\}\left(R e_{\text {max }}^{p}\right)^{-0.16}$

Superscript $\mathrm{p}$ in $f^{\prime}$ represents the time at which the friction factor is evaluated. As the air velocity varies during melting, $\left(R e_{\max }^{p}\right)$ changes with time, $R e_{\max }$ and $G_{\max }$ are calculated based on the $\mathrm{u}_{\max } . \mathrm{u}_{\max }$ is the maximum velocity occurring in the tube bank. Detailed information is given in (Holman and White, 1992). Pumping/fan power is given in Eq. (17).

$W_{\text {fan }}^{p}=(\dot{\forall})_{\text {air }}^{p} \frac{\Delta P^{P}}{\eta_{\text {fan }}}$

$\eta_{f a n}$ is the fan efficiency. The fan is assumed to be ideal, so fan efficiency is taken as 1 .

\section{COMPUTATIONAL ALGORITHM}

The computational algorithm developed for the present study is compared with a study from the literature. While the present study employs the Logarithmic Mean Temperature Difference Method, "LMTD" for the segmented computational domain, Dubovsky et al. 2011 used an alternative approach for their numerical model. They defined a factor, $0 \leq \epsilon \leq 1$ to determine the average air temperature for a specific tube row (computational domain). If this factor is equal to 0 , the average air temperature is attained as the row's inlet temperature. On the other hand, $T_{a v}$ is taken as the air outlet temperature if the value of $\epsilon$ is 1 . For example, the arithmetic average of the inlet and outlet air temperature of the computational domain corresponds to $\epsilon=0.5$. Dubovsky et al. (2011) concluded that the value of the $\epsilon$ is not so crucial for the investigation of the whole time of phase change. It is noted that there is only a $5 \%$ difference between two extreme cases, $\epsilon=0$ and $\epsilon=1$. They have used both numerical and numerical ones and got a perfect match. In the present study, the LMTD method use is preferred to get a more realistic temperature difference between the air and the PCM, instead of using the arithmetic average temperature of the air as the air temperature of the segment. After defining the main dimensions and the tubes' order (aligned or staggered) of the heat exchanger, the computational domain is divided into the number of tube rows. For a specific time step, thermal calculations are conducted in each tube row one by one. Fundamental energy balance is applied using the LMTD method. Some parameters like melt ratio, air temperature, heat transfer is recorded for any tube row and instant. In general, calculations are conducted for a constant total mass of the PCM. After defining the total mass of the PCM, the diameter of the tubes is determined. As the main dimensions of the HEX, the distance between the tubes and the PCM density are known, diameter and the number of the tubes are calculated using this information. Depending on the arrangement of the tubes, aligned or staggered order heat transfer and pressure drop correlations are employed. The distinctive part of the present study is that evaluating the air velocity variable with respect to time. Suppose the total heat absorbed by the PCM for a specific time step is lower than the specified minimum heat transfer requirement. In that case, the mean air velocity is increased by $0.5 \%$ so that the minimum heat transfer requirement is satisfied. Performance of the HEX is evaluated using "Performance Ratio". A schematic representation of the computational algorithm is given in Fig. 4. 


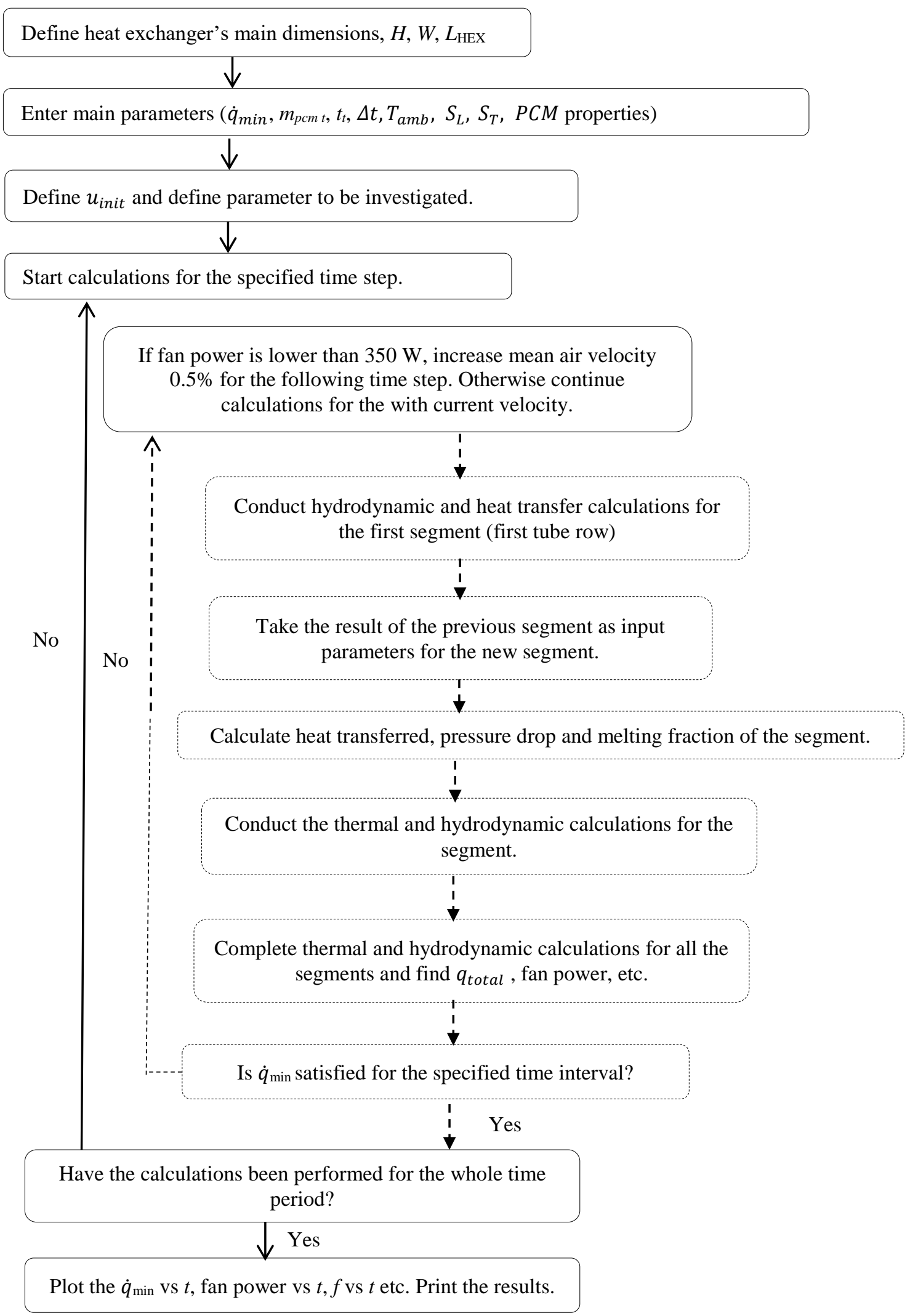

Figure 4. Computational algorithm (Dashed lines represent calculation for a time step)

\section{Computer Code Validation}

The developed thermal model is validated using a typical study from the literature (Letan and Ziskind, 2006; Dubovsky et al., 2011). The computational algorithm is implemented in MATLAB environment. For the same geometry and the operating conditions, the present study results are compared with Dubovsky et al. (2011)'s. Operating conditions and the dimensions of the HEX given by Dubovsky et al. (2011) are presented in Table 2. 
Table 2. Dimensions and the operating conditions of Dubovsky et al. (2011)

\begin{tabular}{|c|c|}
\hline$A_{\mathrm{o}, \mathrm{t}}$ & $32 \mathrm{~m}^{2}$ \\
\hline$m_{\mathrm{pcm}}$ & $60 \mathrm{~kg}$ \\
\hline$h_{\mathrm{sl}}$ & $206 \mathrm{~kJ} / \mathrm{kg}$ \\
\hline$N_{\mathrm{T}}$ & 14 \\
\hline$N_{\mathrm{L}}$ & 90 \\
\hline$k_{\text {pcm }}$ & $0.2 \mathrm{~W} /(\mathrm{m} \cdot \mathrm{K})$ \\
\hline$\dot{m}_{\text {air }}$ & $0.277 \mathrm{~kg} / \mathrm{s}$ \\
\hline$h_{\text {air }}$ & $86 \mathrm{~W} /\left(\mathrm{m}^{2} \mathrm{~K}\right)$ \\
\hline$D_{\mathrm{i}}$ & $0.01 \mathrm{~m}$ \\
\hline$D_{\text {out }}$ & $0.012 \mathrm{~m}$ \\
\hline$T_{\mathrm{m}}$ & $23^{\circ} \mathrm{C}$ \\
\hline$T_{\text {in }}$ & $35^{\circ} \mathrm{C}$ \\
\hline
\end{tabular}

The melting analysis of the PCM-air heat exchanger has been conducted using the computational algorithm presented in Fig. 4 for the same dimensions and the conditions used in Dubovsky et al. (2011). This comparison is presented in Fig.5 and Fig. 6.
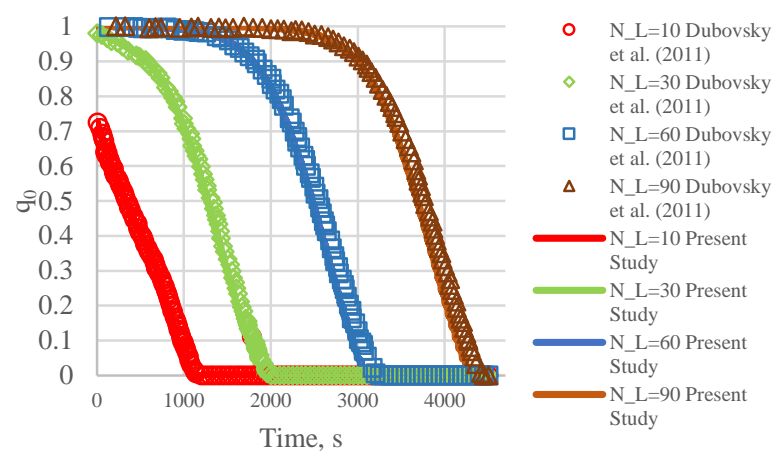

Figure 5. Comparison of present study (solid lines) with Dubovsky et al. (2011) (markers)

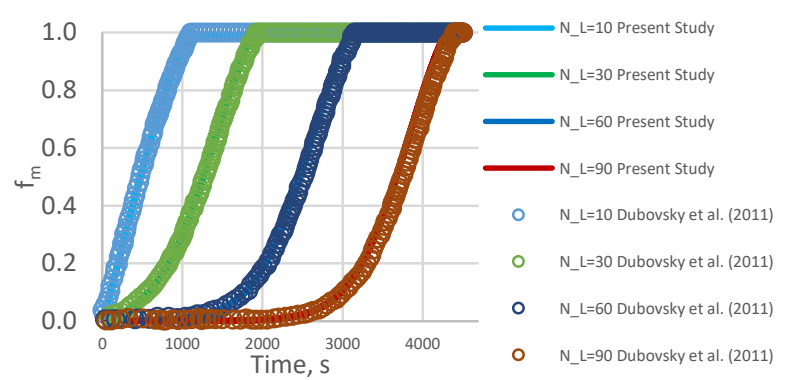

Fig. 6 Comparison of melt fraction of present study (solid lines) with Dubovsky et al. (2011) (markers)

Dubovsky et al. (2011) have investigated the PCM-air heat exchanger's melting characteristics with a numerical and an analytical method. The results of the analyses using these methods have not led to significant discrepancies. Numerical results of the present study are compared with Dubovsky et al. (2011)'s analytical results in Fig. 5 and Fig. 6. A very good match is obtained. It is obvious that for the higher number of tube rows, it takes longer for the last tube row to reach a fully liquid phase. The reason is that the last tube rows contact with heated air, so the melting process takes longer. Because of the melting process's natural characteristics, total heat stored by the PCM reduces with time for the constant airflow velocity. Because the liquid film layer is formed, and this layer creates an additional thermal resistance. This resistance increases while the melting process takes place. In Fig. 5, a sharp decrease in heat transfer is observed after a specific time for all the cases. The mean air velocity should be increased during melting to keep the heat transfer constant. It is possible to keep the heat transfer value over a particular value using a variable speed fan. Thus, the present study has focused on how the pumping power requirement could be kept low while the minimum cooling requirement is satisfied for a certain time period. Parameters affecting the pumping energy requirement are tube placement, size, PCM amount, PCM melting temperature. The effect of these parameters on the design of the PCM-air heat exchanger is investigated.

\section{MAIN DIMENSIONS AND OPERATING CONDITIONS}

Cold energy storage unit performance is evaluated as parametric analysis and dimensional optimization (performance ratio comparison).

\section{Geometry and Operating Conditions for Parametric Analysis}

Firstly, it is aimed to understand the effect of the air mean velocity, PCM mass, and thermal conductivity on fan power and the heat transfer for a fixed HEX geometry. After determining the melting characteristics of the PCMair Hex, a dimensional optimization study is conducted for a constant PCM mass. The main geometry and operating conditions are presented in Table 3.

Table 3. System geometry and inspected parameters

\begin{tabular}{|c|c|}
\hline $\begin{array}{c}\text { Size of the } \\
\text { system }\end{array}$ & $L_{\mathrm{HEX}}=1.35 \mathrm{~m}, W=0.8 \mathrm{~m}, H=0.8 \mathrm{~m}$ \\
\hline$m_{\mathrm{pcm}}$ & $230 \mathrm{~kg}$ \\
\hline$S_{\mathrm{T}}$ & $30 \mathrm{~mm}$ \\
\hline$S_{\mathrm{L}}$ & $30 \mathrm{~mm}$ \\
\hline$t_{\text {tube }}$ & $0.2 \mathrm{~mm}$ \\
\hline$\dot{q}_{\text {min }}$ & $2850 \mathrm{~W}$ \\
\hline$q_{\text {total }}$ & $14.25 \mathrm{kWh}$ \\
\hline$T_{\mathrm{R}}$ & $25^{\circ} \mathrm{C}$ \\
\hline$T_{\mathrm{m}}$ & $18^{\circ} \mathrm{C}$ \\
\hline$\Delta t$ & $0.5 \mathrm{~s}$ \\
\hline$u_{\infty, \text { init }}$ & $0.3 \mathrm{~m} / \mathrm{s}$ \\
\hline
\end{tabular}

The commercial Rubitherm RT18HC's thermophysical properties are employed, and its thermophysical properties are given in Table 4.

Table 4. Properties of the PCM, RT18HC (Khan et al., 2016)

\begin{tabular}{|c|c|}
\hline Melting Temperature, $T_{\mathrm{m}}$ & $18^{\circ} \mathrm{C}$ \\
\hline Latent heat of fusion, $h$ & $250 \mathrm{~kJ} / \mathrm{kg}$ \\
\hline Specific heat capacity & $2 \mathrm{~kJ} /(\mathrm{kg} \mathrm{K})$ \\
\hline Density of solid, at $15^{\circ} \mathrm{C}, \rho_{s}$ & $880 \mathrm{~kg} / \mathrm{m}^{3}$ \\
\hline Density of liquid, at $25^{\circ} \mathrm{C}, \rho_{l}$ & $770 \mathrm{~kg} / \mathrm{m}^{3}$ \\
\hline $\begin{array}{c}\text { Thermal conductivity (both phases), } \\
k_{\mathrm{pcm}}\end{array}$ & $0.2 \mathrm{~W} /(\mathrm{m} \mathrm{K})$ \\
\hline
\end{tabular}


PCM filled tubes are made of aluminum $\left(k_{\mathrm{AL}}=205 \mathrm{~W} /(\mathrm{m}\right.$ $\mathrm{K})$ ).

\section{Dimensional Optimization and Performance Ratio Evaluation}

Optimization parameters for the melting analysis of the present study is summarized in Table 5 .

Table 5. Synthesis of the technical specification requirements

\begin{tabular}{|c|c|}
\hline Function: & Cooling load $(2850 \mathrm{~W})$ for $5 \mathrm{~h}$ \\
\hline Objective: & $\begin{array}{l}\text { Maximization of the perf. ratio } \\
\text { (minimization of fan energy } \\
\text { consumption) }\end{array}$ \\
\hline Constraint: & $\begin{array}{l}\text { HEX main dimensions }(H, L, W) \\
\qquad P P_{\text {air }} \lesssim 350 \mathrm{~W}\end{array}$ \\
\hline $\begin{array}{c}\text { Design } \\
\text { variables: }\end{array}$ & $\begin{array}{l}\text { Parametric analyses: thermal } \\
\text { conductivity, air velocity, PCM mass } \\
\text { Optimization: } S_{L}, S_{T} \text {. }\end{array}$ \\
\hline $\begin{array}{l}\text { Examined } \\
\text { Cases: }\end{array}$ & $\begin{array}{c}\text { Tube arrangement } \\
\text { (Aligned/Staggered), } u_{\infty, \text { init }}\end{array}$ \\
\hline $\begin{array}{c}\text { Fixed } \\
\text { parameters: }\end{array}$ & $\begin{array}{c}\text { PCM mass, room comfort } \\
\text { temperature, } \\
\text { melting temperature, cooling load }\end{array}$ \\
\hline
\end{tabular}

As stated in the Introduction section, airspeed varies during melting. If the required cooling is not satisfied, the mass flow rate of the channel is increased. Maximum allowed air velocity is limited such that fan/pumping power would not exceed $350 \mathrm{~W}$. If this fan power value is reached during the melting process, fan velocity is not increased further. This value is chosen considering the fan specifications on the market.

The performance ratio of cold energy storage HEX is compared for different $S_{\mathrm{L}}$ and $\mathrm{S}_{\mathrm{T}}$ combinations for aligned and staggered orders. Total HEX volume and PCM mass are kept constant for the sake of comparison. A grid search optimization algorithm is employed in the present study (Türkakar and Okutucu-Özyurt, 2012). The design variable interval is divided into grids, and for each $S_{\mathrm{L}}$ and $\mathrm{S}_{\mathrm{T}}$ combination, the performance ratio is determined. Among these values, the minimum one is recorded as optimum geometry. The grid interval is determined to be $0.5 \mathrm{~mm}$. This means the performance ratio is calculated for $21 \times 21$ combination of $\mathrm{S}_{\mathrm{L}}$ and $\mathrm{S}_{\mathrm{T}}$ for the design variables interval of $25 \leq S_{\mathrm{L}} \leq 35$ and $25 \leq S_{\mathrm{T}} \leq 35$. It has been decreased to $0.1 \mathrm{~mm}$ to understand the effect of grid interval on the optimum geometry and the performance ratio. In this case, the performance ratio is calculated for $101 \times 101$ combination of $\mathrm{S}_{\mathrm{L}}$ and $\mathrm{S}_{\mathrm{T}}$. This procedure is applied for the conditions presented for the first row of Table 7 (Aligned, $u_{\infty, \text { init }}=0.3 \mathrm{~m} / \mathrm{s}$ initial velocity, of $25 \leq S_{\mathrm{L}} \leq 35$ and $25 \leq S_{\mathrm{T}} \leq 35$ case). The augmented resolution caused $3.4 \%$ and $4.8 \%$ deviations for the optimum dimensions of $S_{\mathrm{L}}(29 \mathrm{~mm})$ and $S_{\mathrm{T}}(31.3 \mathrm{~mm})$. The performance ratio for these optimum dimensions is found as 263.8 , which corresponds to a $2.5 \%$ difference. The increased resolution has not yielded significant discrepancies, but it tremendously increased the computational effort. A similar check has been performed for the time interval. A time interval of $0.5 \mathrm{~s}$ is utilized for the optimization procedure. As a check, the optimization code is run for a smaller time step $(\Delta t=0.1 \mathrm{~s})$ for the conditions presented in the first row of Table 7. Optimum dimensions have been found the same with the $\Delta t=0.5 \mathrm{~s}$ case. Only $0.1 \%$ deviation has been observed for the performance ratio. Therefore, it can be concluded that a time interval of $0.5 \mathrm{~s}$ is quite enough to get accurate results.

Table 6. Optimization parameters

\begin{tabular}{|c|c|}
\hline Objective Function & Performance ratio \\
\hline & $25 \leq S_{\mathrm{L}} \leq 35$ \\
& $25 \leq S_{\mathrm{T}} \leq 35$ \\
\cline { 2 - 2 } Design Variables & $35 \leq S_{\mathrm{L}} \leq 45$ \\
& $35 \leq S_{\mathrm{T}} \leq 45$ \\
\hline Grid Interval & $0.5 \mathrm{~mm}$ \\
\hline Fan Power & $P P_{\text {air }} \lesssim 350 \mathrm{~W}$ \\
\hline$u_{\infty, \text { init }}$ & $0.2,0.25,0.3 \mathrm{~m} / \mathrm{s}$ \\
\hline
\end{tabular}

Operating conditions and sizes, which are not presented in Table 6 for the optimization study, are taken from Table 3 and Table 4. It is guaranteed that the optimum geometries shown in Table 7 satisfy $\dot{q}_{\min }$ value of 2850 $\mathrm{W}$. However, this criterion might not be satisfied for some combinations of $S_{\mathrm{L}}$ and $S_{\mathrm{T}}$.

\section{RESULTS}

A parametric analysis has been conducted to understand the melting phenomena in cold energy storage HEX. After determining critical values satisfying the system's cooling load like mean air velocity, PCM mass, and fan power, optimum arrangement, and the dimensions have been determined.

\section{Parametric Analysis}

Unlike the other analyses in this section, a transient heat transfer analysis has been conducted for constant velocity. By doing so, the melting characteristics of the PCM at constant velocity is discovered in Fig. 7. For the rest of the analyses, heat transfer is desired to be slightly higher or equal to the minimum cooling load using a variable speed fan. Contrary to the computational algorithm explained in Fig. 4, air velocity is kept constant in the analysis depicted in Fig 7.

Heat transfer during melting at constant velocity is examined for five different air velocities in Fig. 7. Corresponding $\mathrm{Re}_{\max }$ values for the air velocities from lowest to highest are 1843, 2304, 2764, 3225, and 3686. As can be understood from Fig. 7, heat transfer performance gets poorer towards the end of the 5 hours of the cooling period due to the increment in the liquid form and the decreasing melting energy $\left(m_{s} h_{s l}\right)$. As the liquid form in the tubes develops, total thermal resistance (PCM to air) increases. Variation in the heat transfer during the cooling period causes deviations in the temperature for the place to be cooled. Hence, using an adjustable speed fan in the HEX, a stable heat transfer during the melting process is achieved. 


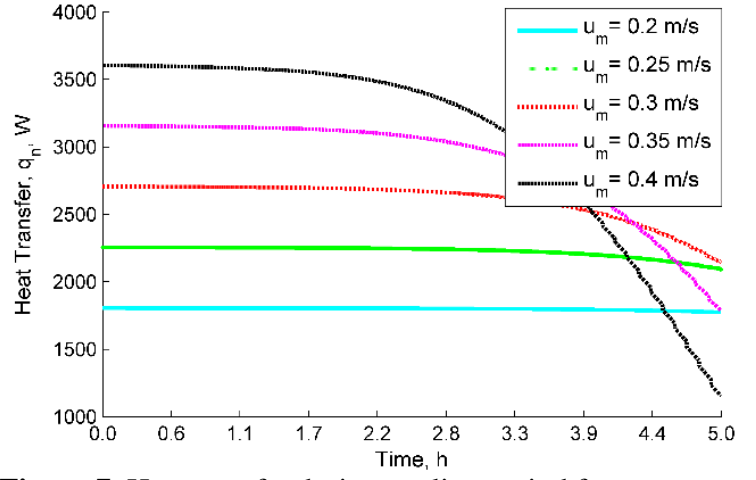

Figure 7. Heat transfer during cooling period for constant velocity, $\mathrm{m}_{\mathrm{pcm}}$, total $=230 \mathrm{~kg}$ (Aligned, $\mathrm{S}_{\mathrm{T}}=30 \mathrm{~mm}, \mathrm{~S}_{\mathrm{L}}=30 \mathrm{~mm}$, $\mathrm{D}_{0}=24.7 \mathrm{~mm}$ )

To design an economically feasible cold storage HEX, the total mass of the PCM used in the system should be minimized. The total amount mass satisfying the constant cooling load of $2850 \mathrm{~W}$ for 5 hours $(14.25 \mathrm{kWh})$ is sought in the analysis shown in Fig. 8.

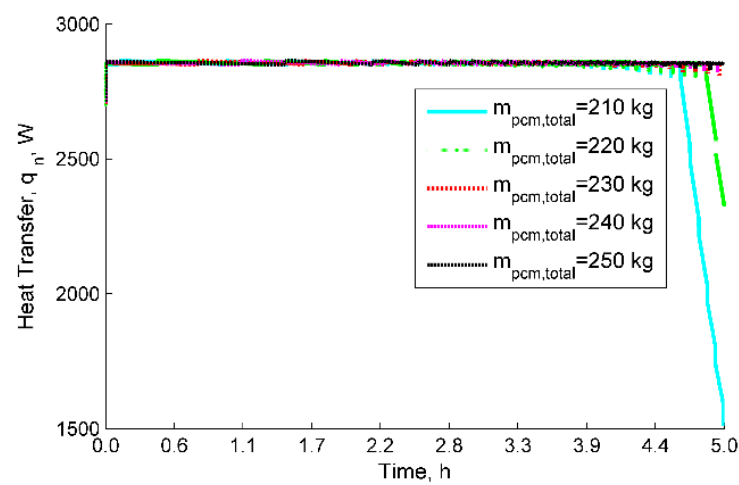

Figure 8. Heat transfer during cooling period for variable speed fan, (Aligned, $S_{\mathrm{T}}=30 \mathrm{~mm}, S_{\mathrm{L}}=30 \mathrm{~mm}$ )

The minimum mass required to keep the building at room comfort temperature is found as $230 \mathrm{~kg}$. Although the system's air mass flow rate is increased, especially after $14000^{\text {th }}(3.88 \mathrm{~h})$ second, the minimum heat transfer requirement could not be satisfied for 210 and $220 \mathrm{~kg}$ PCM. Small fluctuations observed in heat transfer value stems from the air velocity variation during melting. The heat transfer performance of the system sharply reduces for these two cases. Fan power requirements with respect to the time of these cases are presented in Fig 9.

For all the cases, fan velocity increases towards the end of the 5 hours of the cooling period. Fan velocity is increased during the melting process because the liquid film's thermal resistance formed during melting brings about an increase in the system's total thermal resistance. As can be seen from Fig. 5 and Fig. 7, this situation reduces the system's heat transfer performance, especially at higher melt fraction values. The air-side heat transfer coefficient is increased to overcome increasing thermal resistance caused by the liquid film formation. In this way, the system's total thermal resistance is kept constant during melting. PCM mass equal to or higher than $230 \mathrm{~kg}$ successfully completed the cooling period. A lower mass than $230 \mathrm{~kg}$ could not satisfy the cooling load requirement despite reaching the critical pumping power $(350 \mathrm{~W})$ at the end of the cooling period. It could be inferred from Fig. 8 and Fig. 9 that the minimum mass requirement should be $230 \mathrm{~kg}$.

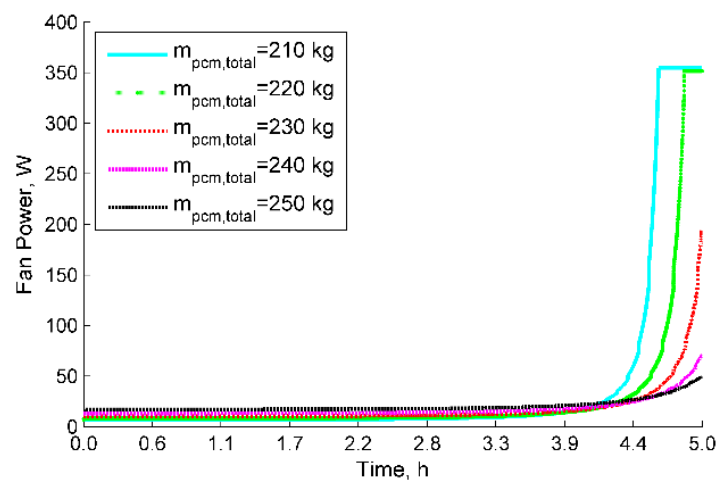

Figure 9. Fan power requirement of the system (Aligned, $S_{\mathrm{T}}=$ $30 \mathrm{~mm}, S_{\mathrm{L}}=30 \mathrm{~mm}$ )

Total thermal resistance between PCM-air can be diminished using highly conductive PCM or using thermal enhancement methods. Khan et al. (2016) summarized thermal enhancement methods for paraffinbased PCM's. They noted that the most common methods are the use of fins in the storage unit and the use of highly conductive additives. They also emphasized the importance of the PCM container's shape and orientation. Aydin et al. 2018 have improved the horizontally placed shell and tube PCM container's thermal performance using a fin attached to the bottom of the inner tube. Cheng et al. (2010) have improved paraffin-based PCM's thermal conductivity 4 times with the addition of expanded graphite. They have reached the $1.36 \mathrm{~W} /(\mathrm{m} \cdot \mathrm{K})$ thermal conductivity value of the PCM composite with the $4.6 \%$ mass fraction of expanded graphite. The effect of thermal conductivity on fan power is presented in Fig. 10 .

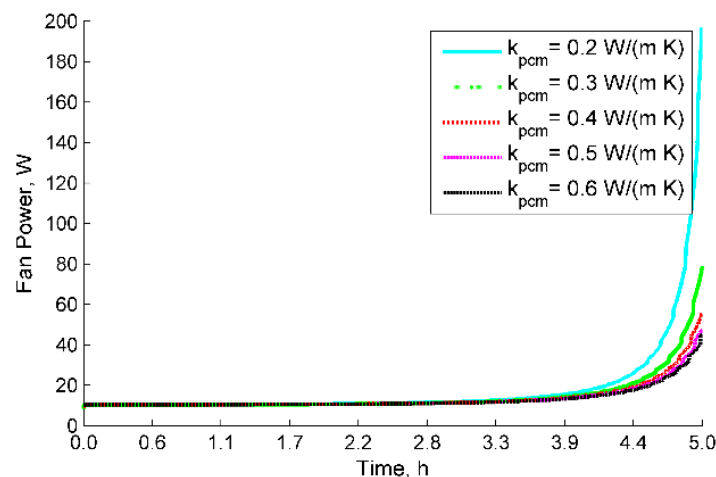

Figure 10. The effect of thermal conductivity of the PCM on fan power at constant heat transfer (Aligned, $S_{\mathrm{T}}=30 \mathrm{~mm}, S_{\mathrm{L}}=30$ $\mathrm{mm}, q_{n} \cong 2850 \mathrm{~W}, m_{\text {pcm,total }}=230 \mathrm{~kg}$ )

Thanks to the reduction in the liquid PCM layer's conductive thermal resistance in the tubes, PCM with 0.6 $\mathrm{W} /(\mathrm{m} \cdot \mathrm{K})$ thermal conductivity requires the lowest fan energy consumption with $(0.065213 \mathrm{kWh})$. This value corresponds to the average fan power of $13.04 \mathrm{~W}$ for 5 
hours melting period. While the total fan energy consumption at the end of 5 hours cooling period for $k_{\mathrm{pcm}}=$ $0.2 \mathrm{~W} /(\mathrm{m} \cdot \mathrm{K}$ ) case $0.089607 \mathrm{kWh}$ (average fan power of $17.92 \mathrm{~W}$ ), it is $0.065213 \mathrm{kWh}$ for the thermal conductivity value of $0.6 \mathrm{~W} /(\mathrm{m} \cdot \mathrm{K})$. By increasing the thermal conductivity three times, fan energy consumption has been decreased $27.2 \%$. It is important to note that all cases satisfied the minimum heat transfer requirement. The algorithm has kept the heat transfer value at $2850 \mathrm{~W}$ by increasing the air velocity if necessary. There is still solid phase in some tubes near the air outlet at the end of the melting period. The last tube row gives an idea about the solid portion in the HEX. The melting ratio of the last tube row of the inspected cases are presented in Fig. 11.

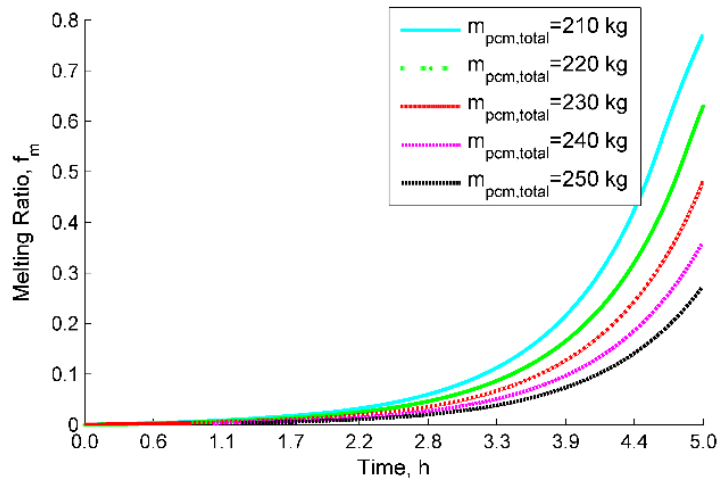

Figure 11. Melting ratio of the last row tubes for different $m_{p c m, t}$, (Aligned, $S_{\mathrm{T}}=30 \mathrm{~mm}, S_{\mathrm{L}}=30 \mathrm{~mm}$ )

There is still the solid phase at the end of 5 hours of the melting process for all cases. Although $230 \mathrm{~kg}$ PCM use is enough to fulfill the present study's cooling requirement, more than half of the total PCM is still solid at the end of 5 hours for the last row of the tubes. This means there is still cold energy stored in the PCM. It is important to note that tube rows close to the air inlet region melt faster, and they are completely melted at the end. Fig 11 shows the melt fraction of the last tube row through which heated airflows.

\section{Performance Analysis and Dimensional Optimization}

Optimum configuration of the PCM-air HEX has been sought in this section. According to the algorithm provided in the "Dimensional Optimization and Performance Ratio Evaluation" section. The performance ratio is the ratio of the energy used for cooling to the energy consumed as fan work for the total time. This ratio is significant in terms of system performance. A higher value of the performance ratio means high cooling capacity and low fan energy consumption. An optimum configuration of the tubes can be found using this ratio. Optimum distance between the tubes in the airflow direction and transverse air flow direction can be found. Fig. 12 and Fig. 13 show the performance ratio for aligned and staggered order arrangement, respectively.

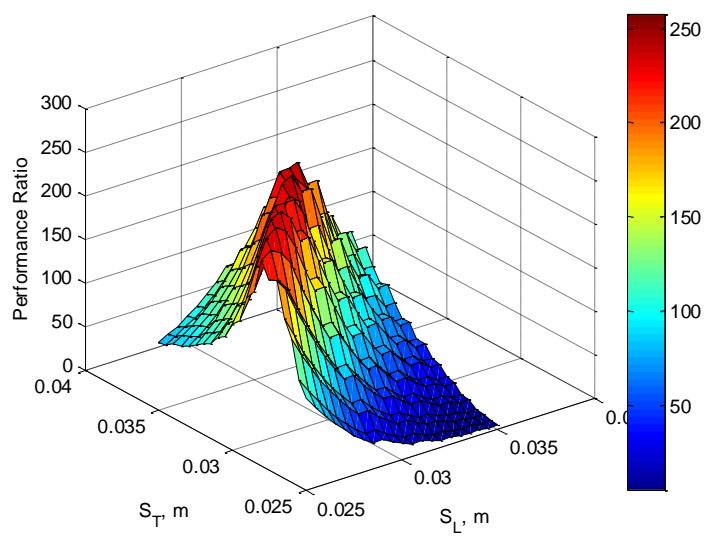

Figure 12. Effect of heat exchanger configuration to performance ratio for aligned order $\left(m_{\mathrm{pcm}, \mathrm{t}}=230 \mathrm{~kg}, u_{\infty, \text { init }}=\right.$ $0.3 \mathrm{~m} / \mathrm{s}$ )

The maximum performance of the heat exchanger is obtained as 257.2 for optimum configuration of $S_{\mathrm{L}}=30 \mathrm{~mm}$ and $S_{\mathrm{T}}=32.5 \mathrm{~mm}$. For larger values of $\mathrm{S}_{\mathrm{L}}$ and $\mathrm{S}_{\mathrm{T}}$ heat exchanger performance reduces. Keeping the tubes distant from each other necessitates the use of larger diameter tubes. As a result, the heat transfer area for one tube increases but it reduces in total. While distant tubes are advantageous in terms of pressure drop and heat transfer, it reduces the total heat transfer area, thus it causes poor heat transfer performance. Therefore, it is better to use closely packed narrow tubes to some extent but after a critical point, it negatively affects the pressure drop.

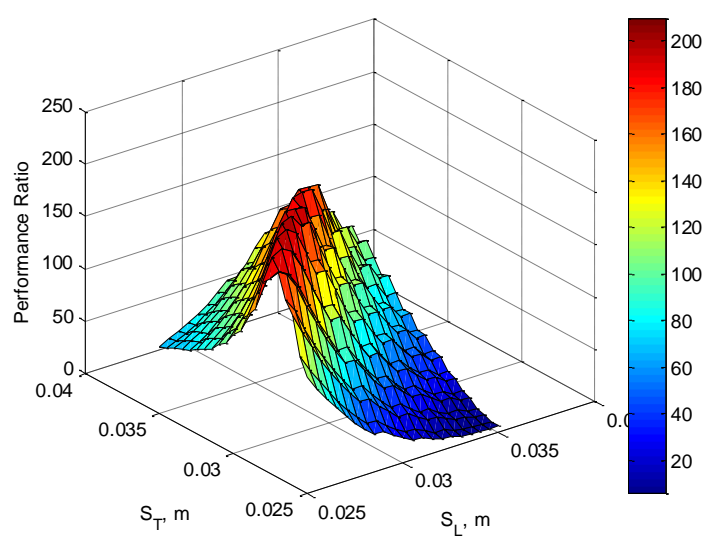

Figure 13. Effect of heat exchanger configuration to performance ratio for staggered order $\left(\mathrm{m}_{\mathrm{pcm}, \mathrm{t}}=230 \mathrm{~kg}\right.$, $\left.u_{\infty, \text { init }}=0.3 \mathrm{~m} / \mathrm{s}\right)$

The heat exchanger's maximum performance is obtained as 209.8 for optimum configuration of $S_{\mathrm{L}}=27 \mathrm{~mm}$ and $S_{\mathrm{T}}=29$ $\mathrm{mm}$. When compared to aligned order, staggered order performs $18.4 \%$ worse. If the $S_{L}$ and $S_{T}$ are kept shorter than the optimum values, the pressure drop remarkably increases.

When Fig. 7 is examined, heat transfer at the beginning of the melting process varies depending on the air velocity. As the optimum dimensions strongly depend on the air's initial velocity, the optimization procedure is applied for different 
initial air velocities. Optimum configurations for different initial velocities are provided in Table 7.

According to the results presented in Table 7 , the maximum performance ratio among the examined conditions is obtained for $0.2 \mathrm{~m} / \mathrm{s}$ initial velocity case. At this value, although the minimum heat transfer requirement is barely satisfied, fan energy consumption is very low. For the $0.3 \mathrm{~m} / \mathrm{s}$ initial velocity value case, slightly higher heat than the minimum requirement is transferred, but the fan energy demand is high. When the fan power is not an issue $\left(u_{\infty, \text { init }}=0.2 \mathrm{~m} / \mathrm{s}\right)$, the optimum $S_{\mathrm{L}}$ gets the lowest value $(25 \mathrm{~mm})$ of the design interval, the optimum $S_{\mathrm{T}}$ gets the maximum value $(35 \mathrm{~mm})$ of the design interval. On the other hand, the $\mathrm{S}_{\mathrm{L}}$ and $\mathrm{S}_{\mathrm{T}}$ 's optimum values are somewhere in the middle of the design intervals for higher initial velocity values. Results show that optimum distances between the tubes in transverse and the longitudinal directions get closer so that the performance ratio is maximized, and the fan energy consumption is reduced at higher velocities. To understand the effect of the design variables interval $\left(35 \leq S_{\mathrm{L}} \leq 45,35 \leq S_{\mathrm{T}} \leq 45\right)$, an alternative analysis has been conducted for $0.3 \mathrm{~m} / \mathrm{s}$ initial velocity case. The use of distant and larger diameter tubes in the HEX has resulted in poor performance ratio. For the lower values of the initial velocity $(0.2$ and $0.25 \mathrm{~m} / \mathrm{s})$, the minimum cooling limit could not be satisfied for the larger design variable intervals for $S_{\mathrm{L}}$ and $\mathrm{S}_{\mathrm{T}}\left(35 \leq S_{\mathrm{L}} \leq 45\right.$ and $35 \leq S_{\mathrm{T}} \leq$ $45)$, even for the optimized cases. Therefore, they are not presented in Table 7. The difference between the lower and the upper limit of the design variables interval could not be increased further than the presented values because the distance between the tubes should be higher than the outer tube diameter. For the constant initial velocity value, aligned order arrangement has performed better for all cases. Although the staggered order's thermal performance is enough or even better for most of the cases, it causes high fan energy consumption.

It was previously explained that there are many studies conducting research on the thermal enhancement of the PCMs. It has been succeeded that the thermal conductivity of paraffin wax is increased to $1.36 \mathrm{~W} /(\mathrm{m} \cdot \mathrm{K})$ using expanded graphene. Staying on the safe side $\left(k_{\mathrm{pcm}}=\right.$ $0.6 \mathrm{~W} /(\mathrm{m} \cdot \mathrm{K}))$, the optimization procedure is applied for the same conditions used for Table 7 except the PCM's thermal conductivity. The results are shown in Table 8 .

If the results of Table 8 are interpreted, higher performance ratios are obtained compared to the low thermal conductivity scenario for all cases. The most dramatic increase is observed for larger design variable interval cases $\left(35 \leq S_{\mathrm{L}} \leq 45,35 \leq S_{T} \leq 45, u_{\infty, \text { init }}=\right.$ $0.3 \mathrm{~m} / \mathrm{s}$ ). Performance ratios increase 4.58 and 3.52 times for aligned and staggered orders, respectively. The use of larger diameter tubes has become reasonable for higher thermal conductivity cases. Higher thermal conductivity has improved the thermal and hydrodynamic

Table 7. Optimum Configurations $\left(m_{\mathrm{pcm}, \mathrm{t}}=230 \mathrm{~kg}, k_{\mathrm{pcm}}=0.2 \mathrm{~W} /(\mathrm{m} \cdot \mathrm{K})\right)$

\begin{tabular}{|c|c|c|c|c|c|c|c|c|c|}
\hline$u_{\infty, \text { init }}$ & $\begin{array}{c}\text { Order* } \\
\text { A/S }\end{array}$ & $\begin{array}{l}\text { Opt. } S_{\mathrm{L}} \\
\mathrm{mm}\end{array}$ & $\begin{array}{c}\text { Opt. } \\
S_{\mathrm{T}}, \mathrm{mm}\end{array}$ & $\begin{array}{l}\text { Design Var. } \\
\text { Interval of } S_{\mathrm{L}}\end{array}$ & $\begin{array}{l}\text { Design Var. } \\
\text { Interval of } S_{\mathrm{T}}\end{array}$ & $\begin{array}{l}\text { Opt. } \\
D_{\mathrm{i}}, \\
\mathrm{mm}\end{array}$ & $\begin{array}{l}\text { Heat Tr., } \\
\text { kWh }\end{array}$ & $\begin{array}{c}\text { Fan } \\
\text { Energy } \\
\text { Cons, } \\
\text { kWh }\end{array}$ & $\begin{array}{l}\text { Perf. } \\
\text { Ratio }\end{array}$ \\
\hline \multirow{4}{*}{$\begin{array}{l}0.3 \\
\mathrm{~m} / \mathrm{s}\end{array}$} & $\bar{A}$ & 30 & 32.5 & \multirow{2}{*}{$25 \leq S_{\mathrm{L}} \leq 35$} & \multirow{2}{*}{$25 \leq S_{\mathrm{T}} \leq 35$} & 20.6 & 14.3426 & 0.055764 & 257.2 \\
\hline & $\mathrm{S}$ & 27 & 29 & & & 18.4 & 14.4334 & 0.068787 & 209.8 \\
\hline & $\mathrm{A}$ & 35 & 39 & \multirow{2}{*}{$35 \leq S_{\mathrm{L}} \leq 45$} & \multirow{2}{*}{$35 \leq S_{\mathrm{T}} \leq 45$} & 24.1 & 14.34 & 0.0807 & 177.8 \\
\hline & $\mathrm{S}$ & 35 & 37 & & & 23.5 & 14.28 & 0.09883 & 144.5 \\
\hline \multirow{2}{*}{$\begin{array}{l}0.25 \\
\mathrm{~m} / \mathrm{s}\end{array}$} & $\bar{A}$ & 26 & 34 & \multirow{2}{*}{$25 \leq S_{\mathrm{L}} \leq 35$} & \multirow{2}{*}{$25 \leq S_{\mathrm{T}} \leq 35$} & 19.5 & 14.32 & 0.016628 & 861 \\
\hline & $S$ & 25 & 32.5 & & & 18.8 & 14.40 & 0.02482 & 580.3 \\
\hline \multirow{2}{*}{$\begin{array}{l}0.2 \\
\mathrm{~m} / \mathrm{s}\end{array}$} & $\mathrm{A}$ & 25 & 35 & \multirow{2}{*}{$25 \leq S_{\mathrm{L}} \leq 35$} & \multirow{2}{*}{$25 \leq S_{\mathrm{T}} \leq 35$} & 19.6 & 14.2768 & 0.011763 & 1213.7 \\
\hline & $S$ & 25 & 35 & & & 19.6 & 14.2786 & 0.017131 & 833.5 \\
\hline
\end{tabular}

*A: Aligned, S: Staggered.

Table 8. Optimum Configurations $\left(m_{\mathrm{pcm}, \mathrm{t}}=230 \mathrm{~kg}, k_{\mathrm{pcm}}=0.6 \mathrm{~W} /(\mathrm{m} \cdot \mathrm{K})\right)$

\begin{tabular}{|c|c|c|c|c|c|c|c|c|c|}
\hline$u_{\infty, \text { init }}$ & $\begin{array}{c}\text { Order* } \\
\text { A/S }\end{array}$ & $\begin{array}{l}\text { Opt. } S_{\mathrm{L}}, \\
\mathrm{mm}\end{array}$ & $\begin{array}{c}\text { Opt. } \\
S_{\mathrm{T}}, \mathrm{mm}\end{array}$ & $\begin{array}{l}\text { Design Var. } \\
\text { Interval of } S_{\mathrm{L}}\end{array}$ & $\begin{array}{l}\text { Design Var. } \\
\text { Interval of } S_{\mathrm{T}}\end{array}$ & $\begin{array}{c}\text { Opt. } \\
D_{\mathrm{i}}, \\
\mathrm{mm}\end{array}$ & $\begin{array}{l}\text { Heat Tr., } \\
\text { kWh }\end{array}$ & $\begin{array}{c}\text { Fan } \\
\text { Energy } \\
\text { Cons, } \\
\text { kWh }\end{array}$ & $\begin{array}{l}\text { Perf. } \\
\text { Ratio }\end{array}$ \\
\hline \multirow{4}{*}{$\begin{array}{l}0.3 \\
\mathrm{~m} / \mathrm{s}\end{array}$} & $\mathrm{A}$ & 30 & 35 & \multirow{2}{*}{$25 \leq S_{\mathrm{L}} \leq 35$} & \multirow{2}{*}{$25 \leq S_{\mathrm{T}} \leq 35$} & 21.4 & 14.8507 & 0.027503 & 539.9 \\
\hline & $\mathrm{S}$ & 30.5 & 35 & & & 21.7 & 14.8091 & 0.037427 & 395.7 \\
\hline & $\mathrm{A}$ & 36.5 & 45 & \multirow{2}{*}{$35 \leq S_{\mathrm{L}} \leq 45$} & \multirow{2}{*}{$35 \leq S_{\mathrm{T}} \leq 45$} & 26.7 & 14.6550 & 0.017799 & 814.2 \\
\hline & $\mathrm{S}$ & 38.5 & 45 & & & 27.5 & 14.4926 & 0.028436 & 509.6 \\
\hline \multirow{2}{*}{$\begin{array}{c}0.25 \\
\mathrm{~m} / \mathrm{s}\end{array}$} & $\mathrm{A}$ & 25 & 35 & \multirow{2}{*}{$25 \leq S_{\mathrm{L}} \leq 35$} & \multirow{2}{*}{$25 \leq S_{\mathrm{T}} \leq 35$} & 19.6 & 14.7755 & 0.009902 & 1492.1 \\
\hline & $\mathrm{S}$ & 26 & 35 & & & 19.9 & 14.6424 & 0.015666 & 934.6 \\
\hline \multirow{2}{*}{$\begin{array}{l}0.2 \\
\mathrm{~m} / \mathrm{s}\end{array}$} & $\mathrm{A}$ & 25 & 35 & \multirow{2}{*}{$25 \leq S_{\mathrm{L}} \leq 35$} & \multirow{2}{*}{$25 \leq S_{\mathrm{T}} \leq 35$} & 19.6 & 14.2795 & 0.007641 & 1868.6 \\
\hline & $S$ & 25 & 35 & & & 19.6 & 14.2813 & 0.011310 & 1262.7 \\
\hline
\end{tabular}

*A: Aligned, S: Staggered. 
performance of the system. The question is 'could the minimum cooling be satisfied with $220 \mathrm{~kg}$ PCM with increased thermal conductivity?' Although the performance ratio decrement, the answer is yes for all the cases in Table 8. The optimization code is executed for $220 \mathrm{~kg}$ PCM for the aligned cases presented in Table 8. The performance ratio reduction in the order from higher velocity to the lower velocity case are found as $(539.9 \rightarrow$ $392.5,1492.1 \rightarrow 1087.8,1868.6 \rightarrow 1547.1)$. The maximum deviation in the optimum dimensions is found negligible $(1 \mathrm{~mm})$.

\section{CONCLUSION}

Melting analysis of a cold energy storage device has been investigated. It is desired to design such a system that satisfies the minimum cooling requirement $(2850 \mathrm{~W})$ for 5 hours and requires minimum fan energy consumption. An optimum arrangement and the cross-flow tubular PCM-air cold energy storage HEX configuration has been determined using a variable speed fan. By increasing the fan speed during the melting process, heat transfer between the air and the PCM is kept stable.

- It is observed that the heat transfer ratio in the HEX sharply decays, especially at high air velocities (at constant velocity) due to rapid melting rate at earlier stages of the melting, and thus decreasing melting energy.

- Although it is stable at low velocities, the minimum heat transfer requirement could not be satisfied for the constant velocity case. Therefore, it is necessary to use variable-speed fan to keep the room's comfort temperature.

- The minimum PCM mass required to overcome the specified cooling load $(2850 \mathrm{~W}$ for 5 hours, 14.25 $\mathrm{kWh}$ ) is determined to be $230 \mathrm{~kg}$.

- As a result of the optimization study $\left(k_{\mathrm{pcm}}=0.2\right.$ $\mathrm{W} /(\mathrm{m} \cdot \mathrm{K}))$, maximizing the performance ratio, the aligned order performed better than the staggered order for the same design variable interval and the initial velocity of the air.

- The best performance ratio is obtained for the initial velocity of $0.2 \mathrm{~m} / \mathrm{s}$ for both staggered and aligned arrangements. According to the optimization results of this case, while the tubes are closely placed in the longitudinal direction, they are kept distant in the transverse direction.

- For the highest initial velocity value of $0.3 \mathrm{~m} / \mathrm{s}$, space between the tubes in transverse and longitudinal directions becomes closer. At this initial velocity, heat transfer is slightly higher than the minimum limit $(2850 \mathrm{~W})$ initially, but the fan speed is increased afterward because of the worsening thermal performance of the system.

- Although the heat transferred is the maximum for 0.3 $\mathrm{m} / \mathrm{s}$ initial velocity case, the performance ratio is the lowest because of the high fan energy consumption. All the cases tabulated in Table 7 have successfully provided the minimum required cooling. Keeping the tubes distant and using larger diameter tubes has resulted in low-performance ratios.

- If $0.3 \mathrm{~m} / \mathrm{s}$ initial velocity, aligned order, $k_{\mathrm{pcm}}=0.2$ $\mathrm{W} /(\mathrm{m} \cdot \mathrm{K})$ case is inspected, keeping the design variables interval at larger values required $44.7 \%$ higher fan energy consumption for the same heat transfer rate.

- The use of larger diameter tubes has become reasonable for the optimization study performed for $k_{\mathrm{pcm}}=0.6 \mathrm{~W} /(\mathrm{m} \cdot \mathrm{K})$. When compared to low thermal conductivity case, performance ratios increase 4.58 and 3.52 times for aligned and staggered orders, respectively.

- It is possible to save $10 \mathrm{~kg}$ PCM thanks to the enhanced thermal conductivity of the PCM.

\section{REFERENCES}

Asker, M., \& Günerhan, H. (2016). Faz değişim malzemeli isi değiştirici üzerine parametrik bir çalişma. Journal of the Faculty of Engineering and Architecture of Gazi University, 31(3), 555-565. https://doi.org/10.17341/gummfd.76037

Aydin, O., Avci, M., Yazici, M. Y., \& Akgun, M. (2018). Enhancing storage performance in a tube-in shell storage unit by attaching a conducting fin to the bottom of the tube. Isi Bilimi Ve Teknigi Dergisi/ Journal of Thermal Science and Technology, 38(2), 1-13.

Chaiyat, N., \& Kiatsiriroat, T. (2014). Energy reduction of building air-conditioner with phase change material in Thailand. Case Studies in Thermal Engineering, 4, 175186. https://doi.org/10.1016/j.csite.2014.09.006

Cheng, W. L., Zhang, R. M., Xie, K., Liu, N., \& Wang, J. (2010). Heat conduction enhanced shape-stabilized paraffin/HDPE composite PCMs by graphite addition: Preparation and thermal properties. Solar Energy Materials and Solar Cells, 94(10), 1636-1642. https://doi.org/10.1016/j.solmat.2010.05.020

Dhumane, R., Qiao, Y., Ling, J., Muehlbauer, J., Aute, V., Hwang, Y., \& Radermacher, R. (2019). Improving system performance of a personal conditioning system integrated with thermal storage. Applied Thermal Engineering, 147(June 2018), 40-51. https://doi.org/10.1016/j.applthermaleng.2018.10.004

Dubovsky, V., Ziskind, G., \& Letan, R. (2011). Analytical model of a PCM-air heat exchanger. Applied Thermal Engineering, 31(16), 3453-3462. https://doi.org/10.1016/j.applthermaleng.2011.06.031

Erdemir, Dogan, and Necdet Altuntop. 2018. "Effect of Encapsulated Ice Thermal Storage System on Cooling Cost for a Hypermarket." International Journal of Energy Research 42 (9): 3091-3101. https://doi.org/10.1002/er.3971. 
Erkmen, F. İ., Gedik, G.Z., (2007) Örnek Bïr Konutun Farkli Yöntemlerle Hesaplanan Soğutma Yüklerïnin Karşılaştırılması : Antalya Ve Diyarbakır Örneği. İstanbul Ticaret Üniversitesi Fen Bilimleri Dergisi, Y1l 6 Sayı 11, 143-163.

Fang, G., Wu, S., \& Liu, X. (2010). Experimental study on cool storage air-conditioning system with spherical capsules packed bed. Energy and Buildings, 42(7), 10561062. https://doi.org/10.1016/j.enbuild.2010.01.018

Hed, G., \& Bellander, R. (2006). Mathematical modelling of PCM air heat exchanger. Energy and Buildings, 38(2), 82-89. https://doi.org/10.1016/j.enbuild.2005.04.002

Holman, J P, and P R. S. White. Heat Transfer. London: McGraw-Hill, 1992. Print.

Incropera, Frank P, and David P. DeWitt. Fundamentals of Heat and Mass Transfer. New York: J. Wiley, 2002. Print.

Khan, Z., Khan, Z., \& Ghafoor, A. (2016). A review of performance enhancement of PCM based latent heat storage system within the context of materials, thermal stability and compatibility. Energy Conversion and Management, 115, 132-158. https://doi.org/10.1016/j.enconman.2016.02.045

Koz, M., \& Khalifa, H. E. (2018). Phase change material melting in an energy storage module for a micro environmental control system. Journal of Thermal Science and Engineering Applications, 10(6). https://doi.org/10.1115/1.4040896

Kuznik, F., Arzamendia Lopez, J. P., Baillis, D., \& Johannes, K. (2015). Design of a PCM to air heat exchanger using dimensionless analysis: Application to electricity peak shaving in buildings. Energy and Buildings, 106 , $65-73$.
Letan, R., Ziskind, G., Thermal design and operation of a portable PCM cooler. in: M. Kutz (Ed.), Heat Transfer Calculations. McGraw-Hill, New York, 2006 (Chapter 39)

Souayfane, F., Fardoun, F., \& Biwole, P. H. (2016). Phase change materials (PCM) for cooling applications in buildings: A review. Energy and Buildings, 129, 396431. https://doi.org/10.1016/j.enbuild.2016.04.006

Türkakar, G., \& Okutucu-Özyurt, T. (2012). Dimensional optimization of microchannel heat sinks with multiple heat sources. International Journal of Thermal Sciences, 62 , https://doi.org/10.1016/j.ijthermalsci.2011.12.015 $85-92$.

Yang, N., Zhang, X., Li, G., \& Hua, D. (2015). Assessment of the forced air-cooling performance for cylindrical lithium-ion battery packs: A comparative analysis between aligned and staggered cell arrangements. Applied Thermal Engineering, 80, 55-65. https://doi.org/10.1016/j.applthermaleng.2015.01.049

Zhao, D., \& Tan, G. (2015). Numerical analysis of a shelland-tube latent heat storage unit with fins for airconditioning application. Applied Energy, 138, 381-392. https://doi.org/10.1016/j.apenergy.2014.10.051

Zukauskas, A. "Heat Transfer from Tubes in Cross Flow," Adv. Heat Transfer, vol. 8, pp. 93-160, 1972.

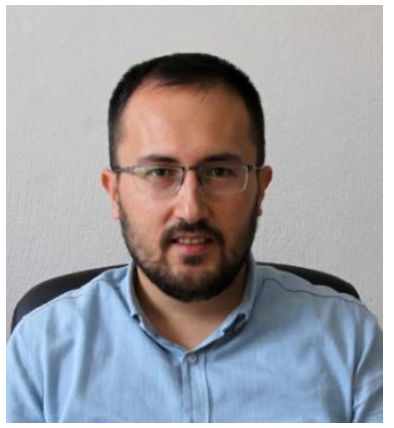

Göker TÜRKAKAR received BS degree from Mechanical Eng. Dept, Osmangazi University, 2006 Eskisehir Turkey. He obtained his MS on 2010 from Mechanical Eng, Middle East Technical University (METU), Ankara, Turkey. He got his PhD degree from Mech Eng, METU in 2016. He joined Thermal Analysis, Microfluidics and Fuel Cell Lab in Rochester Institute of Technology on March 2015 (9 months) as a visiting scholar. He focused on designing a microscale refrigeration cycle for electronics cooling in his Ph.D. study. He works as a faculty member in Mechanical Department of Zonguldak Bülent Ecevit University since 2017. 